\title{
IMPLICATIONS OF THE INTERNET FOR QUASI-LEGISLATIVE INSTRUMENTS OF REGULATION
}

\section{Peter L. Strauss*}

It is a quarter century since I began telling my Administrative Law students that they had better be watching the Internet and how agencies of interest to them were using it, as they entered an Information Age career. The changes since then have been remarkable. Rulemaking, where the pace has perhaps been slowest, is now accelerating into the Internet, driven by a President committed to openness and consultation. This paper seeks little more than to point the reader toward the places where she can find the changes and watch them for herself.

Il y a un quart de siècle que j'ai commencé à dire à mes étudiants en droit administratif qu'ils feraient bien de surveiller l'Internet et comment les agences qui les intéressent s'en servent, au moment où ils entreprenaient une carrière à l'ère de l'information. Les changements depuis lors ont été remarquables. L'élaboration de règles, où l'évolution a peut-être été la plus lente, s'accélère maintenant à l'Internet, mené par un Président qui s'est engagé à l'ouverture et à la consultation. Cet article ne vise pas plus que d'indiquer à la personne qui le lit les endroits où elle peut trouver les changements et les surveiller pour ellemême.

\section{INTRODUCTION}

Our exploding experience with technology has extraordinary implications across the full range of governmental activities. As Vivek Kundra, the United States' Chief Information Officer, remarked at a recent press conference in San Francisco, "technology deployed for public service can fundamentally change how a government and its people interact." "At the time, he and others were addressing the delivery of government services - creating a common platform for municipal service calls (311) that would permit using Twitter in any city to report a need for pothole repair was the repeated example. The focus in this paper is on a more limited set of developments not on the delivery of services, but on the formation and to a lesser extent the implementation of policy through agency quasi-legislation.

The Information Age has spawned two dominating changes in visibility/accessibility and, perhaps, participation respecting the development of agency regulations ("tertiary legislation," in EU parlance; "subsidiary legislation," often in national systems) and guidance instruments ("soft law"): first, the emergence of readily searchable, universally accessible Internet data sets permitting immediate, essentially cost-free, and universal access to government information bearing on proposed regulatory actions, the proposals themselves, comments and data supplied by others, and the regulations or guidance documents that result; and, second, the

Betts Professor of Law, Columbia University School of Law. Deep thanks to Cynthia Farina, proactive and deeply engaged in these issues as the following pages will attest, who has been generous with comments and suggestions; Natalie Orpett provided valuable research assistance. Responsibility for these pages is mine alone.

1 "US Chief Information Officer Press conference" (2 March 2010), online: SFGTV

$<$ http://san-francisco.granicus.com/Media-Player.php?publish_id=557>. 
development of interactive sites permitting persons to enroll for notice of developments of possible interest to them, and to submit commentary on proposals that concern them. My hope for this paper is to spark a conversation about these developments, as and if they are evidencing themselves in our respective legal cultures, and their possible implications for the future of quasi-legislative administrative action.

The legitimacy of permitting unelected officials to create binding legal texts is an enduring problem for any democracy. "In an era when executive authority seems to be growing at the cost of parliamentary accountability," Genevieve Cartier wrote in the Canadian context, "democratic control over policy-making seems ever more urgent." "The literature about the European Union often invokes a "democracy deficit" in discussing the regulation-like "implementing measures" that emerge there as tertiary legislative instruments, corresponding to agency regulations in the USA. ${ }^{3}$ "Implementing measures" emerge from the shadowy process of "comitology," a hidden and bureaucratic process whose very name suggests arcane mysteries and possible intrigue." Hence the "democracy deficit." In the United States, one can without difficulty ascribe a similar problem to agency regulations; although adopted following a procedure involving both public notice, public participation, and explanation, nonetheless the adopters are appointed, not elected, officials. They lack the legislative connection of ministers in parliamentary democracies. The possible influence of an elected President arguably increases, rather than diminishes, the problem. $^{5}$

The growth in executive authority Professor Cartier wrote about has proved inevitable in our complex age. A century ago, the U.S. Supreme Court found violation of the Secretary of Agriculture's rules governing the grazing of sheep in national forests, seen as an inevitable filling in of the details of a statute authorizing his administration of those lands, to be in and of itself a basis for sending someone to jail. $^{6}$ Today, regulations emerge from agencies at ten to twenty times the rate Congress produces statutes,' and "soft law," influential though not formally binding,

2 Genevieve Cartier, "Procedural Fairness in Legislative Functions: The End of Judicial Abstinence?" (2003) 53 UTLJ 217 at 218.

3 These measures are two levels below the EU's constitutive treaties and one below its statute-like "secondary" measures - regulations and directives adopted by its Parliament and Council, that acquire legitimacy through the involvement of the European Parliament (and, to a lesser extent, a Council composed of persons who are politically responsible on a national level), as well as the public manner in which they are considered. See e.g., Paul Craig \& Grainne De Burca, EU Law: Text, Cases and Materials 4th ed (Oxford: Oxford University Press, 2007) at 134; Giandomenico Majone, "Europe's 'Democracy Deficit': The Question of Standards" (1998) 4 Eur LJ 5.

4 On these processes generally, see Peter L. Strauss, Turner Smith, \& Lucas Bergkamp, "Rulemaking" in George Bermann et al, eds, Administrative Law of the European Union (Washington D.C.: ABA, 2008).

5 Peter L. Strauss, “Overseer or 'The Decider' - the President in Administrative Law” (2007) 75 Geo Wash L Rev 695; Peter L. Strauss, “Presidential Rulemaking” (1997) 72 Chicago-Kent L Rev 965.

$6 \quad$ United States v. Grimaud, 220 U.S. 506 (1911).

7 Congress enacts four hundred or so public laws annually; estimates of annual regulatory production I have seen range between 4000 and 8000; no one counts soft law instruments, but at technical agencies at least its volume is enormous - particularly as contemporary ideas about rulemaking 
is created in greater volumes still. This phenomenon is reflected in a hierarchy of legal texts that I believe can be found in every developed economy:

Foundation document(s), adopted by "the nation"

Hundreds of statutes, adopted by an elected legislature

Thousands of regulations, adopted by politically responsible executive officials

Tens of thousands of interpretations and other guidance documents, issued by responsible bureaus

Countless advice letters, press releases, and other statements of understanding, generated by individual bureaucrat

We understand passably well the ordering and influence of the top three layers of this hierarchy. Legal systems treat each of them as binding text, subject only to the requirements that they be authorized by the superior authority and appropriately adopted following designated procedures; if valid, each of them has legislative effect on government and citizen alike, until displaced by another text validly adopted at the same or a higher level. It is on passing from the second to the third tier that the "democracy deficit" problem rears its head. We understand, too, that the innumerable informal items of the fifth tier, while often in fact influential on private conduct, are denied any jural effect. We would find some confusion on the fourth, "soft law" tier confusion whether these documents are legitimate instruments of agency policy, or a ruse to evade the higher procedural obligations associated with adopting regulations; confusion whether an agency may give them any jural effect and, if so, to what degree; and confusion whether and to what extent they must be respected by the courts. ${ }^{8} \quad$ And soft law documents, much less often given the imprimatur of the Ministers, Secretaries or Administrators who head political agencies, present the "democracy deficit" problem in even sharper outline.

In another essay," I have explored the question whether Americans can find a satisfying resolution of the deficit in the "strong unitary executive theory" popular among some American academics - that is, the claim that our elected President is entitled to decide all policy issues Congress may have delegated to the various Departments and administrative agencies of our government. As would not surprise anyone familiar with my earlier writings, ${ }^{10} \mathrm{I}$ concluded there that reconciling delegated executive authority of a law-making character with democratic ideals on a theory of

encourage the adoption of malleable standards setting goals for achievement rather than precise rules prescribing particular courses of action The regulated then earnestly and understandably seek guidance about ways in which they might be able to meet those standards.

8 On this subject see Peter L. Strauss, "Publication Rules in the Rulemaking Spectrum: Assuring Proper Respect for an Essential Element” (2001) 53 Admin L Rev 803; for a similar understanding of the Canadian situation, see Laura Pottie \& Lorne Sossin, "Demystifying the Boundaries of Public Law: Policy, Discretion, and Social Welfare” (2005) 38 UBC L Rev 147

9 Peter L. Strauss, “Legislation that Isn't: Attending to Rulemaking's Democracy Deficit” (2010) 98 Cal L Rev at 1351.

10 Strauss, supra note 5. 
voter-ratified political will is deeply unsatisfying, if not hazardous to our rule-of-law culture. We tolerate agency specification of, for example, permitted pollutant levels only because it involves acts of reasoned judgment, within frameworks established by statutes and subject to judicial review. "We must so construct the President's relation to government as to permit the enduring belief that we live in a rule-of-law culture of constrained reasonable judgment, even as we recognize the contributions that political will can make."”

My ambitions here are different - to explore the variety of ways in which governmental use of the Internet may engage citizens in the world of quasi-legislation and in doing so, just possibly, provide its own response to the "democracy deficit." The paragraphs following will draw primarily on the developments at the level of American federal government, with occasional reference to state practice and to the practices of the European Union. ${ }^{2}$ Their intention is, simply, to provide a framework for further discussion and documentation of progress in our respective legal systems.

\title{
II. SECRET LAW
}

\author{
"We hear of tyrants, and those cruel ones: but, whatever we may \\ Have felt, we have never heard of any tyrant in such sort cruel, \\ As to punish men for disobedience to laws or orders \\ Which he had kept them from the knowledge of." ${ }^{13}$
}

The first case in which the United States Supreme Court held a congressional statute to be invalid as an excessive delegation of authority ${ }^{14}$ dramatized the problem of secret law. A depression-era statute had given the President certain authority to control interstate commerce in petroleum and its products, as a means of stabilizing prices; and he and the Secretary of the Interior (to whom he had subdelegated this power) had adopted rules in the exercise of that authority. When the validity of this statute came before the Supreme Court (all but one of whose members would find it to be standardless), the government was embarrassed to admit that a reexamination of the relevant documents (which at the time were not publicly available) had revealed that the Secretary had inadvertently revoked the relevant regulation before the lawsuit had been filed. ${ }^{15}$ " $[1 \mathrm{t}$ was shocking that the government attorneys, the private parties, and the courts had not been aware of the status of the regulation. 'The furor resulting from the hot oil case provided the final impetus for the enactment of remedial

11 Strauss, supra note 9 at n 86.

12 Drawing on European Union Administrative Law, supra note 4.

13 Jeremy Bentham, The Works of Jeremy Bentham (Edinburgh, UK: William Tait, 1843) vol 5 at 547; Erwin N Griswold used this as the epigram to his "Government in Ignorance of the Law--A Plea for Better Publication of Executive Legislation” (1934) 48 Harv L Rev 198, discussed in text at n 17 below.

14 Panama Refining Co. v. Ryan, 293 U.S. 388 (1935).

15 Ibid at $412-413$. 
legislation [the Federal Register Act] in 1935."'16 Just the prior year, only weeks before the argument and decision in the case - perhaps even sensing what would likely transpire - Erwin Griswold (later to become Dean of Harvard Law School and US Solicitor General) had argued passionately and persuasively the need for "a reasonable means of distributing and preserving the texts of ... executive-made law." ${ }^{17}$ The Federal Register, a daily gazette of executive branch documents including rules and rulemaking proposals, was the result.

The Federal Register, like such publications generally, was a useful but imperfect response to the problem of secret law. A bulky daily publication, with an ambitious yet (necessarily) limited index, its effective use required lawyers and librarians. Moreover, it was incomplete. While regulations were included, "soft law" documents - guidance and interpretations - generally were not. Access to "soft law" might be possible - the federal Administrative Procedure Act $[A P A]$ encouraged its public availability and indexing by provisions prohibiting its use to the disadvantage of private parties unless it was available and indexed ${ }^{18}$ - but that access might require travel to one of a limited number of agency reading rooms, or perhaps to a specific agency office. Just what might constitute a qualifying index was nowhere specified, and one can readily imagine many obstacles to its detail. If not precisely secret, then, regulatory law was often obscure and access to it expensive.

Providing further relief from the problems of secret law is perhaps the most obvious use of the Internet. In 1994 the Federal Register and in 1996 the Code of Federal Regulations (where adopted regulations are eventually collected) were embedded and made readily searchable at the website of the Government Printing Office, ${ }^{19}$ one of the first important federal e-government projects. They are now available as well on for-profit and non-profit sites such as Lexis and Cornell's Legal Information Institute. ${ }^{20}$ Each agency's electronic reading room, required by law, ${ }^{21}$ holds regulations, guidance, interpretations, staff manuals - any quasi-legislative document in which the public might be interested..$^{22}$ If Boolean search is enabled, the documents are not only there, but also exquisitely indexed, in a manner no print edition or document filing system could hope to achieve. The interventions of

16 Mary Whisner, "Practicing Reference ... A Manual 'to Inform Every Citizen”" (2007) 99 Law Libr J 159 at 160, citing Morris L. Cohen, Robert C. Berring \& Kent C. Olson, How To Find The Law, 9th ed (St. Paul: Westlaw, 1989) at 265.

17 Griswold, supra note 13. Griswold was on the staff of the Solicitor General's office until 1934, when Panama Refining was briefed; Thus he could easily have been aware of the coming firestorm; his article was published in the December, 1934 issue of the Law Review; argument in Panama Refining was held that month, and the decision announced in January 1935.

185 U.S.C. 551 (a) $(1,2)$.

19 Code of Federal Regulations, online: US Government Printing Office $<$ http://www.gpo- access. gov/index.html>.

20 See Cornell University Legal Information Institute, online: Cornell University Legal Information Institute < http://www.law.cornell.edu/cfr/ $>$.

21 Required in America at the national level by the Electronic Freedom of Information Act Amendments of 1966, Pub. L. 104-231, Oct. 2, 1996, 110 Stat. 3048, amending 5 U.S.C. \$552(a)(2).

22 See e.g. online: FAA < http://www.faa.gov/regulations_policies/>, collecting a wide range of soft law documents as well as FAA regulations. 
librarians and lawyers are no longer required (although they may still be useful); if the document is in the electronic library, it cannot be "off the shelf" and on someone else's desk.

One of the more important regulations issued by the Department of Transportation's National Highway Traffic Safety Administration [NHTSA] has been its Standard 208, ${ }^{23}$ requiring the installation first of seatbelts and then of airbags in American automobiles. Understandably, manufacturers and others have had questions about the requirements of the standard, and interpretation of its provisions, which they have addressed to NHTSA's General Counsel. His interpretive letters responding to their inquiries have always been public documents, but access to them once depended on either visiting his office in Washington, D.C. or finding an industry group or member that had made its own collection. One can imagine both the expense of hiring a lawyer to perform that search, and the imperfections of the filing system she would encounter. Enter the website NHTSA has been maintaining for years, collecting the opinion letters of its Chief Counsel, making them available for Boolean search, ${ }^{24}$ and promising their reliability. ${ }^{25}$ Its enterprise so impressed General Motors and an industry group that had begun electronic recordkeeping years before NHTSA supplemented its paper files, that they each donated their electronic records of earlier letters for inclusion in the searchable repository. Now using an Internet connection half a continent (or half the world) away from Washington, anyone wishing to learn NHTSA's interpretations of Standard 208 (or any of its other regulations) reliably has that information in seconds. The visibility of government law, hard and soft, has been exponentially increased.

To be sure, even this simplest and most obvious use remains a work in process. The European Union offers a single search-enabled Internet gateway to "legislation,"

Federal Motor Vehicle Safety Standards And Regulations, 49 CFR Parts 552, 571, 585, and 595

See National Highway Traffic Safety Administration, online: NHTSA: < http://isearch.nhtsa.gov/>.

See National Highway Traffic Safety Administration, online: <http://www.n-h-t-s- a.dot.gov/ portal/site/nhtsa/menuitem.4d1e17245-efafde89-ec0f-210dba046-a0>. The Chief Counsel's promise, "The Chief Counsel's interpretations, issued in the form of letters responding to questions from the motor vehicle industry and the public, represent the definitive view of the agency on the questions addressed and may be relied upon by the regulated industry and members of the public," may be contrasted by the disclaimers many agencies post with their soft law (responding to unfortunate signals sent by judicial review cases). The Food and Drug Administration, for example, attaches this standard disclaimer to its guidance ("soft law") documents:

This guidance represents the Food and Drug Administration's (FDA's) current thinking on this topic. It does not create or confer any rights for or on any person and does not operate to bind FDA or the public. You can use an alternative approach if the approach satisfies the requirements of the applicable statutes and regulations. If you want to discuss an alternative approach, contact the FDA staff responsible for implementing this guidance. If you cannot identify the appropriate FDA staff, call the appropriate number listed on the title page of this guidance. See, e.g. Guidance for Industry, FDA Staff, and Third Parties - Inspection by Accredited Persons Under The Medical Device User Fee and Modernization Act of 2002 and the FDA Amendments Act of 2007; Accreditation Criteria, online: <http://www.fda.gov/Medical-Devices/Device-Regulation- andGuidance/GuidanceDocuments/ucm089702.htm>. 
both enacted ${ }^{26}$ and under consideration, ${ }^{27}$ where "Legislation" is understood to comprise all binding texts (i.e., tertiary as well as secondary measures), as well as "certain important non-binding acts." There is no uniform way to access either EC or American agencies' soft law files. ${ }^{28}$ Other national practices remain highly variable. At the state and local level in the USA, access even to regulations may still be haphazard, and soft law is not yet readily accessible. ${ }^{29}$ Converting paper documents to electronic ones requires resources and incentives; both may be in short supply. (This problem will prove even more prominent in the following sections of this essay). One readily imagines, however, that this kind of use of the Internet will be the fastest to become universal, with the result that the world of "secret law" will shrink significantly, if not wholly disappear. ${ }^{30}$

\section{KNOWING WHAT QUASI-LEGISLATORS KNOW AND WHAT THEIR PLANS ARE}

In American contemplation, the "democracy deficit" associated with quasilegislation creates often rigorous judicial attention to the rationality of its exercise. Although (absent possible implications for important rights) American courts barely consider the rationality of legislation or the regularity of legislative procedures when they review legislation for constitutionality, the procedures prescribed for quasilegislation and the rationality of the judgments it reflects are strongly checked, particularly in matters of high economic or social consequence. One characteristic opinion, reviewing an Environmental Protection Agency rule with major economic

26 See Europa, Eur Lex, online: <http://eur-lex.europa.eu/en/legis/index.htm>; see Cynthia Farina, Sidney Shapiro and Thomas Susman, "Transparency and Data Protection in ABA Section of Administrative Law and Regulatory Practice" in Bermann et al., supra note 6 at $21 \mathrm{ff}$.

27 See ibid. Europa Pre Lex, online: <http://ec.europa.eu/prelex/apcnet.cfm?CL=en>.

28 In the Department of Transportation, for example, the FAA guidance is accessed directly from a "Regulations \& Policies" tab prominent at the top of its home page; NHTSA guidance, however, much less prolix, requires one to know to follow the FOIA link obscure at the bottom of the home page to FOIA Electronic Reading Room.

29 The California Office of Administrative Law, for example, offers what appears to be comprehensive access to regulations adopted by California agencies but no access to soft law, other than manuals of the Department of Social Services, online: OAL < http://www.oal.ca.gov/>; the web site of its Department of Agriculture gives no hint that that vital department harbours any soft law. Online: CDFA < http://www.cdfa.ca.gov/Regulations.html>. In New York, the equivalent office warns on its website, indexing state agencies, that "If you are seeking regulations regarding a specific area, a number of New York State agencies now make their rules and regulations available online. Others document their statutory authority.” Online: Government of New York < http://www.g-O-rr.state.ny.us/Regulatory-Reform/current-regulations.htm>.

30 One cannot doubt that certain documents government agencies use to establish standards for their employees' behaviour - "law" in the important sense that it marks the practical limit of state tolerance for private actions - will be kept secret in the interest of avoiding manipulative or challenging behaviors. If, for example, state police are secretly instructed to issue speeding tickets only to motorists who exceed the legal speed limit by, say, ten miles per hour, that instruction may rationally accommodate predictable differences in speedometer calibration and also serve to focus attention on major violators; for it to be made public, however, would invite faster driving by many and might eliminate the margin of error the practice creates. 
consequences for the coal and electric power industry as well as environmental values, consumed 103 pages of an opinion closely attending to the EPA's reasoning and the factual contentions it had to resolve, before remarking in conclusion, "we have taken a long while to come to a short conclusion: the rule is reasonable." 31

The last half-century's developments in American administrative law have witnessed an emphatic growth in the transparency associated with both government information and quasi-legislative planning. Integration of Internet resources into these pre-existing trends is already considerably magnifying its effects.

Start with information. As enacted, the federal Administrative Procedure Act required only that "matters of official record shall in accordance with published rule be made available to persons properly and directly concerned," with a "good cause" confidentiality exception. ${ }^{32}$ The rulemaking procedure generally required public notice of proposed rules with an opportunity for public comment prior to adoption, with a "concise general statement of their basis and purpose" to accompany the adopted rule; in addressing the policy issues involved, the notice need specify "either the terms or substance of the proposed rule or a description of the subjects and issues involved." 33 In 1966, Congress had amended the $A P A$ to give "any person" strongly enforcible rights to see any information in a government agency's possession, to the extent it did not fall within one of nine rather narrow exceptions - a freedom of information measure [FOIA] now commonplace in world legal systems. ${ }^{34}$ In general, ${ }^{35}$ data (as distinct from preliminary policy views) was unprotected from such claims; thus, a request for "all studies likely to be considered in connection with your rulemaking proposed April 2, 2010" would likely have to be honoured (although no formal procedural link is made between a citizen's request and a rulemaking to which that request might relate). Perhaps reacting to the enhanced transparency the FOIA had put in place (dramatically reemphasized by Congress in extensive strengthening amendments it enacted in 1974), and/or the suddenly increasing importance of rulemaking brought about by the great expansion of health and safety regulation in the early 1970 's, courts asserted that notice and comment procedures could not be effective unless the government made available to the public, alongside its proposal, important studies on which the proposal relied. ${ }^{36}$

Enter the Internet. The Electronic Freedom of Information Act Amendments of $1996^{37}$ envisaged moving FOIA activity to the Web - agencies are to have FOIA links on their website, which explain the $A c t$, permit the filing of electronic requests, and - as importantly - are to serve as repositories for frequently requested material, so that it

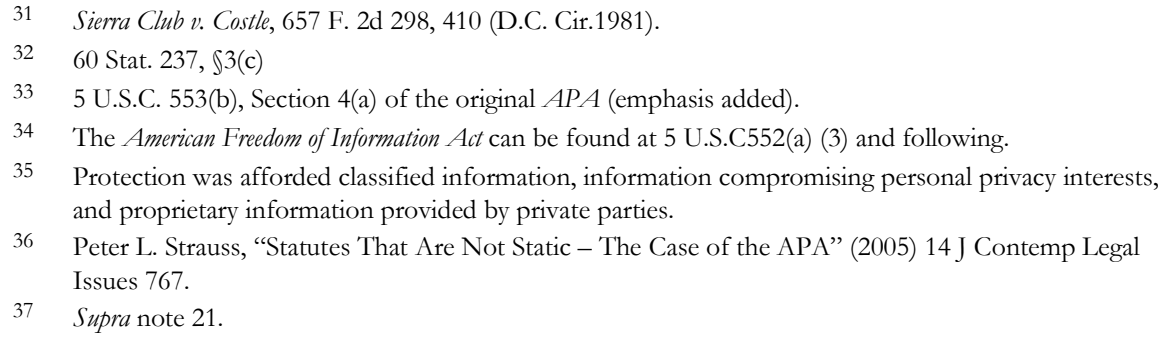


may simply be found there. Now public dockets could be created, to which any relevant documents, including studies, could be posted for ready availability and comment. Agency reaction to these developments was variable and, generally, slow; the most thoroughgoing effort was made by the Department of Transportation, which (at considerable savings for the Department) converted its entire filing system to electronic form - much of it open to public access. Using its Data Management System [DMS], interested members of the public could see every public document associated with a given proceeding, within days of its filing. Supporting studies, earlyfiled comments and the like were thus available to commenters.

The E-Government Act of 2002 emphasized a national commitment to such development. The Act requires agencies to accept comments "by electronic means" and to make available in their e-dockets "public submissions and other materials that by agency rule or practice are included in the rulemaking docket... whether or not submitted electronically.", Although the mandate is qualified by "to the extent practicable," the idea is clearly that the public should be able to find everything in the e-docket that they could find if they went to the agency reading room. Directed to agencies, the Act did not itself require creation of the single, unified electronic data system, but the Bush administration, in implementing it, moved all rulemaking to the Internet through a new portal, Regulations.gov, ${ }^{40}$ and a unified data management system associated with it, the Federal Data Management System [FDMS]. Works in progress, the early difficulties of the $A c t$ s implementation and of Regulations.gov were well captured in a law review article by Beth Noveck, a young law professor who subsequently became a central figure in the Obama Administration's commitments to open government, ${ }^{41}$ and by a report for the American Bar Association ${ }^{42}$ based on the work of Cynthia Farina, another law professor who has since become a central figure in Cornell's Electronic Rulemaking Initiative, discussed below. ${ }^{43}$

One such problem: agency capacity and willingness to migrate to an electronic docket (as DOT had) is mixed, so that for many agencies the FDMS dataset is both incomplete and far from instantaneous, and search capabilities are limited. Even today, not all agencies are uniformly (and timely) putting all materials in rulemaking dockets on to their e-dockets available through Regulations.gov. Changes in

38 Now incorporated into the Federal Data Management System, online: FDMS < http://docketsinfo.dot.gov/ >; the process was complicated by the broader reach of the DMS, which entirely replaced paper dockets at DOT; FDMS, at least initially, could not achieve that universality given variablility in the readiness of different government agencies for such a transition. The transition and its difficulties prompted DOT to create a generally helpful guide for FDMS searches, online: FDMS $<$ http://docketsinfo.dot.gov/FDMS_Tips.cfm>.

39 Sec. 206 (c) (d).

40 Online: Federal Government $<$ http://www.regulations.gov>.

41 Beth Noveck, “The Electronic Revolution in Rulemaking” (2004) 53 Emory LJ 1. Prof. Noveck is currently United States Deputy Chief Technology Officer and Director of the White House Open Government Initiative.

42 Committee on the Status and Future of Federal e-Rulemaking, Achieving the Potential: The Future of Federal E-Rulemaking - A Report to Congress and the President (2008), available online: CERI $<$ http://ceri.law.cornell.edu/erm-comm.php> [ABA Study].

43 See text accompanying note 89 below. 
Regulations.gov and FDMA are occurring with regularity. As recently as April 7, 2010, for example, a memorandum from Cass Sunstein, the Administrator of the White House Office of Management and Budget [OMB]'s Office of Information and Regulatory Affairs [OIRA] directed all agencies to "make it easier for members of the public to find and view [rulemaking] information ... [by using] the Regulation Identifier Number [RIN] on all relevant documents throughout the entire 'lifecycle' of a rulemaking ... [-] documents including, but not limited to, notices of proposed rulemaking, final rules, and (to the extent that they are associated with a rulemaking) notices, guidances, environmental impact statements, regulatory impact analyses, information collections, and supporting materials." ${ }^{, 4}$

The Obama Administration's emphasis on improving government transparency, captured in a presidential Memorandum on Transparency and Open Government issued the day after his inauguration, has also produced an explosion in general data availability (useful for but not necessarily connected to particular rulemakings). One such development, likely to have a direct impact on rulemakings, is agency development of public libraries of scientific reports; the Environmental Protection Agency [EPA]'s recently launched Health and Environment Research Online database ${ }^{45}$ contains over 300,000 scientific studies searchable along a variety of parameters. A central government website, data.gov, not only makes available to public use a rapidly increasing number of machine readable federal datasets, but also links to datasets identified by particular government agencies in response to the OMB's "Open Government Directive," ${ }^{, 46}$ and to the increasing number of state, local and tribal data sites. ${ }^{47} \quad$ Similar initiatives exist - are inevitable - elsewhere. ${ }^{48}$ They permit private creation of programs letting the public use data they find for their own purposes - an NGO could create a searchable database to let people "see" the local effects of sea level rises that may be associated with global warming, just as EPA's Toxic Resource Inventory $^{49}$ now permits anyone to see what toxins are being released in their

44 See online: OMB < http://www.white-house.gov/omb/assets/in-foreg/Increasing-Openness_0407-2010.pdf $>$ While the RIN system has been in place for many years, the problem with using it to track a rule (and electronically map/display its lifetime, in the manner of the European Parliament and Commission sites) is that it has not been consistently used across agencies, or even within a single agency over time. Inconsistency defeats efforts to build rule timelines automatically (actually, it generally makes historical data about rulemaking problematic). The OMB memo is a first step towards defining government-wide consistent practices.

45 See online: EPA < http://www.epa.gov/hero/>.

46 The directive, issued December 8, 2009 to implement President Obama's Memorandum, online: White House < http://www.whitehouse.gov/open/documents/open-government-directive > set April 7, 2010 as a date by which each agency was to publish at least three high-value data-sets in an open (platform independent, machine readable, and unrestricted) format, and every agency subject to the memorandum did so. Online: Federal government <http://www.data.gov/open $>$ and White House < http://www.whitehouse.gov/open/around $>$.

47 See online: OMB < http://www.data.gov/statedatasites>; see online: Data SF (San Francisco) $<$ http://www.datasf.org/> and online: NYC Government (New York City) $<$ http://www.nyc.gov/html/datamine/html/home/home.shtml $>$.

48 See online: Government of UK, <http://data.gov.uk>.

49 See online: EPA < http://www.epa.gov/tri/>; see e.g. Bradley Karkainnen, "Information-forcing Regulation and Environmental Governance" in Grainne de Burca \& Joanna Scott eds, Law and New Governance in the EU and the US (Portland: Hart Publishing, 2006) 293. A similar utility is promised for 2011 respecting carbon dioxide emissions. Michael Gerrard, "Greenhouse Gas Disclosure Requirements Are Proliferating," (April 1, 2010) 243:61 NYLJ. 
neighbourhood. This is not the place to discuss "Government 2.0," but one can readily imagine the transformative impact. The TRI experience is a forceful illustration of what can happen when "the government exposes capabilities that can then be used by the private sector" - to generate pressures, or to build (open-source)

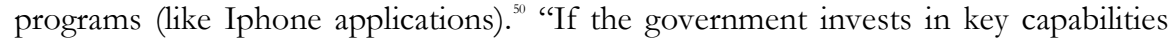
that the private sector can then build on, you get this virtuous circle., ${ }^{\text {s1 }}$

Transparent planning. The text of the $A P A$ does not require the public to learn of potential rulemaking activities before a notice of proposed rulemaking, inviting comment, is published. The notice the $A P A$ requires need not appear until late in the rule development process. Thus it may be that, as one administrative law scholar who had also been EPA's General Counsel once put it, "[n]otice-and-comment rulemaking is to public participation as Japanese Kabuki theater is to human passions - a highly stylized process for displaying in a formal way the essence of something which in real life takes place in other venues." ${ }^{52}$ The Regulatory Flexibility Act had already begun to change this state of affairs in the print era, with a requirement ${ }^{53}$ that agencies semi-annually publish a regulatory agenda briefly describing their planned rulemakings and providing, inter alia, a point of contact within the agency to whom submissions might be made or with whom discussions could be held. The Unified Agenda of April 1994 consumed over 1500 pages in the Federal Register, with as many as six or seven entries per page; there were about 100 pages of index. Initially one of the most difficult elements of the Federal Register to find and search online, it has now been integrated into Regulations.gov. ${ }^{54}$ It can be searched only one agency at a time, search capabilities are limited, and - as indicated - the availability of an RIN number assuring access to all matters in ensuing dockets is, for the moment, uncertain. ${ }^{55}$

American Presidents from Ronald Reagan forward have appeared to wish to build on this process as a means of increasing central coordination and perhaps control of rulemaking activities. President Reagan's Executive Order 12498 added participation in an annual "regulatory plan" to the requirements of cost-benefit analysis of important regulations under the OIRA supervision that he had previously established by his Executive Order 12291. Yet this planning element of what is now a firmly established presidential regime, continued as Section 4 of President Clinton's E.O. 12866, has remained quite obscure. The literature is full of attention to the problems

50 See "US Chief Information Officer Press Conference" supra note 1 at 24:50.

51 Ibid at 26:00 Development can flow back to government as well. The CeRI initiative discussed below, a private effort to help the government improve the e-rulemaking experience, is one example. Another was provided a few years ago by OMBWatch, an NGO monitoring White House activities. Using federal procurement data the Federal Funding Accountability and Transparency Act of 2006 required be made available online, OMBWatch developed <www.fedspending.org $>$ to monitor governmental spending patterns. Impressed, OMB acquired the program and, adapted to its purposes, it can be found online: $\mathrm{OMB}<\mathrm{www}$.usaspending.gov $>$. Information from an E-mail from Gary Bass, OMBWatch (May 6, 2010).

52 E. Donald Elliott, "Reinventing Rulemaking" (1992) 41 Duke LJ 1490 at 1492-93.

535 U.S.C. $\$ 602$.

54 See online: $<$ http://www.regulations.gov/public/component $/$ main?main=UnifiedAgenda $=240>$.

55 See text accompanying note 44 above. 
and potential of the cost-benefit analysis of individual rulemakings called for by Section 6, the effective central element of this regime. But unlike the situation in the

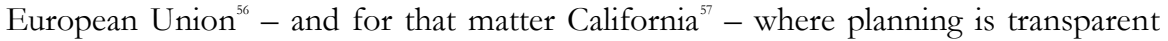
and such consultations as occur begin early, to date neither priority planning nor the early public consultations that might go along with it are well developed in our federal practice. Regulations.gov, for example, offers no chance to submit a request for rulemaking not already undertaken; while the $A P A$ does provide a procedure for petitioning an agency to engage in rulemaking, ${ }^{58}$ this element of its procedures has yet to be given general electronic form. Individual agencies may well do more in the way of providing early notice of projects under development, supplementing this resource. Thus, the EPA has created a rulemaking gateway providing information about the progress of a "priority regulation" from the moment the beginning of work on the project has been approved, without regard to whether it is mentioned in the regulatory plan.

\section{CONSULTATIONS}

We Americans have long prided ourselves on our notice and comment

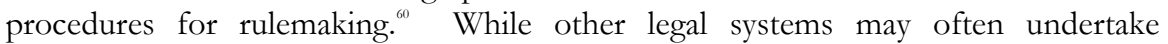
consultation on proposed regulations, that typically occurs within a limited interest community identified by the agency, out of public view and rarely required as a general matter. Of course American agencies may, and indeed sometimes do, conduct "private" consultations in connection with rulemaking, either before notice or as they are attempting to digest the results of the public comment period. ${ }^{61}$ To the extent such private consultations, either inside or outside government, produce consensus around a particular course, they contribute to critical assessments of the public comment process. $^{62}$ Yet the private consultations have a certain odour, ${ }^{63}$

56 The Union's European Commission publishes periodic workplans of the matters currently under consideration, and its YourVoice site at <http://ec.europa.eu/yourvoice/index_enhtm>, offers consultations at quite early stages of proposal development. See text accompanying $\mathrm{n} 4$ above.

57 See online: OAL < http://www.oal.ca.gov/2009_Rulemaking_Calendar_Office_of_Adminis-trativ.htm $>$, showing proposed timeline of development.

585 U.S.C. $\$ 553(\mathrm{e})$.

59 See online: EPA < http://yosemite.epa.gov/opei/rulegate.nsf/content/about.html?opendocument>. Just as APA rulemaking was hitting its stride in the late 1960 's, one of the great scholars of the first APA generation characterized it as "One of the greatest inventions of modern government." Kenneth Culp Davis, Administrative Law Treatise \6.15, (Supp. 1970) at 283.

61 For a sharp critique of this practice at the Federal Communications Commission, see Philip Weiser, "Institutional Design, FCC Reform, and the Hidden Side of the Administrative State" (2009) 61 Admin L Rev 675.

62 Elliott, supra note 52.

63 C.f. Home Box Office v. FCC, 567 F.2d 9 (D.C. Cir. 1977), excoriating the practice of private consultations after a comment period has closed. While the opinion has had limited jural effect, and seems not to have discouraged the FCC in particular, see Weiser, supra note 61, its practical effect on most agencies' behaviour appears to have been considerable, reaching also into the pre-notice period to influence the logging of meetings and contacts. See Sidney A. Shapiro, "Two Cheers for HBO: The Problem of the Nonpublic Record" (2002) 54 Admin L Rev 853; from September 15, 2009, the White House has made public a database of all visitors, downloadable in machine-searchable form. Online: White House <http://www.whitehouse.gov/briefing-room/disclosures/visitor-records> (visited April 22, 2010), and EPA posts the schedules of all its senior administrators' meetings with 
producing strong impulses to transparency - as reflected, for example, in the quite detailed procedures associated with statutory procedures for negotiated rulemaking. ${ }^{64}$ And the nature of "hard look" judicial review (considering only such matters as have come into the public record in support of the adopted rule, and effectively requiring agency response to important comments) has given the comment process force.

In the paper process world, the comment as well as the notice stage of federal agency rulemaking provided a limited opportunity. One filed one's comments in paper, only with the requesting agency, and toward the end of the comment period provided. Consequently, commenters could only expect to address the agency's proposal, not such information or views as others may have provided. Even if one wanted to read the comments of others, and even if there were time to do so, timely physical access would have been difficult if not impossible. In contrast to the consultation practice that, for example, the European Union follows in respect of its possible legislative initiatives, ${ }^{65}$ comments are typically sought relatively late in the regulation-development process - after, for example, initial consultations with OIRA over cost-benefit issues.

Enter the Internet, and many elements of the historic notice-and-comment process might be expected to change. The possibilities of expanded access to materials forming the basis for proposed rules have already been discussed; ${ }^{6 \sigma}$ if filed electronically or converted to electronic form, comments (like soft law documents) can be promptly available nationwide, facilitating response." "Reply" comments become more feasible, and some agencies are in fact experimenting with their use although "wary of extending an already lengthy process and proliferating the number of comments that must be considered." ${ }^{\prime s}$ Associating the capacity to create a comment, government-wide, with a utility that permits ready identification of proposals open for comment and exploration of any data associated with them - this is the basic design of Regulations.gov - lowers the quantum energy barrier to commenting, perhaps considerably. ${ }^{69}$ The ease and costlessness of filing comments

persons from outside EPA, with RSS feeds from each. Online: EPA < http://yosemite.epa.gov/o$\mathrm{pa} /$ admpress.nsf/Calendars?OpenView $>$.

645 U.S.C. \$561 et seq. Although called "negotiated rulemaking," the process is more aptly described as negotiated rule development, since if successful its direct result is not a rule, but a notice of proposed rulemaking generated by a consensual effort among the agency and representatives of interested groups. It thus constitutes a proceduralization of pre-notice consultation practice; although encouraged by many (including several Presidents), its costs and limited successes in practice have resulted in only occasional use of it. See e.g. Stuart Benjamin, "Evaluating ERulemaking: Public Participation and Political Institutions" (2006) 55 Duke LJ 893 at 922.

65 Strauss, supra note 4.

66 See text accompanying note 44 above.

67 Delays can occur, as agencies must authorize comments to be posted, lest inappropriate or properly confidential matter appear. ABA Study, supra note 42 at 56 and n 131.

68 Ibid at 58

69 The site permits browsing by an an impressive number of topics (or keywords); in providing for RSS feeds that might automate notice of developments of interest, however, the site enables subscription only agency by agency. While some Departments have provided sub-units (the Animal and Plant Health Inspection Service, APHIS, and the Forest Service in the Department of Agriculture, for 
on the Internet could broaden the base of commenters, and empower "political campaigns" about controversial rulemaking proposals. ${ }^{70}$ Even a physical postcard comment requires a stamp and the effort to write it out, and carries a postmark; an electronic comment might be filed with a simple click on the website of a soliciting $\mathrm{NGO}$, and received with no reliable indicator from where and from whom it in fact came. Within agencies, using computer-based data files (including the possibility of digital processing of mass communication comments) may make the development of rules more efficient. The rulemaking agency now reaches its judgment in a much more transparent setting, if all can readily access the "record" on the basis of which it acts. Finally, the fact of a consolidated, uniform, and freely accessible "rulemaking record" also permits enhanced White House participation in/oversight of the agency decisional process, that in a paper record world would have been largely inaccessible outside the agency.

As earlier remarked, ${ }^{71}$ the implementation of these changes was sharply criticized in years before the Obama Administration. Regulations.gov is a site in continuing development, and among the products of the transparency commitments of the Obama Administration ${ }^{72}$ has been an "exchange" site for continuing discussion with the public of possible changes." Changes already effected make it possible, if one knows the RIN number of a particular rulemaking, ${ }^{74}$ to subscribe for email notification of any additions to that docket. There remain not inconsiderable difficulties about programming (what kinds of searches the FDMS will permit) and agency resources/effort (willingness/ability/time taken to put all material into the electronic database).

Perhaps the most significant issues, captured in 2006 by a Symposium issue of the Duke Law Journal, ${ }^{75}$ concern the potentially transformative effects of broadscale public participation, converting what has in general proved to be a low-participation level, expert process into a more plebiscitary one. Professor Stuart Benjamin, in one article, $^{76}$ finds the unified system of Regulations.gov particularly troublesome; permitting individual agencies to experiment, he argues, might permit learning whether the benefits of e-rulemaking outweigh what he sees as its potential costs increasing comment quantity without affecting content or result, ${ }^{77}$ while making the

example), others do not - one gets all EPA RSS feeds or none, with no possibility of limitation to the topic, or even office, of particular interest.

On this issue, see generally the work of Stuart Shulman, a political scientist who with others has developed a computerized system for handling mass e-mail comments, briefly described in ABA Study, supra note 42 at 53 \& n 126. See e.g. Stuart Shulman (2009) "The Case Against Mass E-mails: Perverse Incentives and Low Quality Public Participation in U.S. Federal Rulemaking” 1(1) Policy \& Internet, Article 2, online: <http://www.pso-commons.org/policy-and-internet/vol1/iss1/art2>. See text accompanying nn 41-42 above.

See e.g. text accompanying n 44 above.

See online: Regulations.Gov < http://www.regulations.gov/exchange/node>.

See text accompanying $n 44$ above.

75 "Thirty-fifth Annual Administrative Law Issue: The Role of the Internet in Agency Decisionmaking" (2006) 55 Duke LJ. 893 ff.

76 Stuart Benjamin, "Evaluating E-Rulemaking: Public Participation and Political Institutions" (2006) 55 Duke LJ 893.

77 Here he cites a prominent FCC rulemaking on media ownership rules, in which over a million comments were received, but treated by the agency as not "terribly helpful or influential." Ibid at 908 and $n 43$. 
rulemaking process more costly for resource-strapped agencies; and increasing the intrusiveness and effects of congressional oversight and judicial review, to similar effect. There might be a case for modest, skeptical experimentation, but the unified full-speed-ahead approach signaled by Regulations.gov involve costs that are too high, benefits that are too uncertain. ${ }^{78}$ Professor Cary Coglianese, in another article, ${ }^{79}$ remarks that, historically, the median rulemaking has invited only tens of comments, few from individual citizens; while this pattern may be changing with the introduction of electronic comment possibilities, Professor Coglianese (with Professor Benjamin) is skeptical whether quality gains result. If one discards outlier rulemakings inviting a particularly high volume of (politically motivated) commentary from the data, some have reported, he suggests, no dramatic changes in volume - and no changes at all in substantive contribution - have occurred. ${ }^{80}$ "Rather than a revolution in citizen participation, the end result from even ambitious attempts at e-rulemaking seems likely to turn out much less interesting than the high hopes many now seem to harbor." "' Professor John Figueiredo's study of the results of e-rulemaking at a single agency, the Federal Communications Commission, similarly found no more than marginal change. ${ }^{82}$

\section{DIALOGUE?}

The Obama Administration appears committed to exploiting the world of social media to its fullest. One can hardly find a government site lacking blogs, RSS feeds, twitter pages, facebook links, and the like - and in the service not only of "getting the message out," but also receiving input in discussion formats open to participant "ratings" that, in theory at least, will drive the most popular submissions into clearest view. President Obama's open government initiative, coordinated by the White House Office of Science and Technology Policy, has generated ambitious Open Government Plans, ${ }^{83}$ numerous "open" websites, ${ }^{84}$ and similar commitments -

78 See also Stuart Shulman, "Whither Deliberation: Mass E-Mail Campaigns and U.S. Regulatory Rulemaking" 2006) 3 Journal of E-Government 41; Stephen Zavestoski, Stuart Shulman, \& David Schlosberg, "Democracy and the Environment on the Internet: Electronic Citizen Participation in Regulatory Rulemaking," (2006) 31 Science, Technology \& Human Values 383; Steven Balla, \& Benjamin Daniels, "Information Technology and Public Commenting on Agency Regulations" (2007) 1 Regulations \& Governance 46.

79 Cary Coglianese, "Citizen Participation in Rulemaking: Past, Present and Future" (2006) 55 Duke LJ 943.

80 "According to one recent study of about 500,000 comments submitted on an especially controversial EPA rule [addressing airborne mercury levels], less than 1 percent $\ldots$ had anything original to say." Ibid at 959 .

81 Ibid at 968.

82 John Figueiredo, "E-Rulemaking: Bringing Data to Theory at the Federal Communications Commission" (2006) 55 Duke LJ 969.

83 See the EPA's 53-page “Open Government Plan 1.0" available online: EPA < http://www.e-pa.gov/open>.

84 See e.g. the OSTP website < http://www.whitehouse.gov/open, >; in general, one can find an open website at a top-level government website rather than agency-by-agency - for example online: Open 
proliferating at a dizzying rate, defying delimitation much less assessment in a paper such as this. Beth Noveck, whose early paper was mentioned earlier, ${ }^{85}$ has been central to these developments.

And for rulemaking? EPA's elaborate and very recently published "Open Government Plan" includes a heading on "Expanding Public Awareness and Involvement in the Development of Rules and Regulations," but it does not appear to be sponsoring dialogue in that context. Perhaps the commitments and style (to date) of Regulations.gov limits it to an electronic form of the standard "notice and comment" process. The most interesting development in this respect of which I am aware is a university project that one might think a descendant - at least a close relative - of the ABA Report mentioned above. ${ }^{87}$ Cynthia Farina, its Reporter, has also been deeply involved in the Cornell Electronic Rulemaking Initiative [CeRI], an interdisciplinary effort that with the support of the National Science Foundation and the Departments of Commerce and Transportation is working generally to facilitate use of the Internet in rulemaking - and specifically to "[a]ssist $\square$, and actively promot[e], agency experimentation in Internet-based ways to elicit public participation beyond just the notice-and-comment process." One effort, very much in line with the ABA study, has been to model ways in which the Regulations.gov site can be made more open, helpful, even educational for the citizen coming to it. Another, very much in progress as I write, is an experiment in converting a rulemaking to a discussion format. ${ }^{89}$

The Department of Transportation currently has pending a rulemaking proposal that would prohibit most "texting" by commercial drivers whose safe conduct it can directly regulate..$^{\circ}$ CeRI has taken the quite extensive proposed rule and explanation, and summarized it thematically on its "regulationroom" website. On different days, different specific elements of the proposal (for example, how is "texting" to be defined; what drivers are covered; what penalties are provided for) are identified for discussion, and participants see and react to each other's comments on that element. In effect, the discussion collects comments focused on particular elements of the rulemaking, where the ordinary comment process is to the whole of a proposal, as well as facilitating some back-and-forth. At the conclusion of the discussion period, the CeRI staff developed a draft summary - again open to participant input - and the final product was submitted to the Department as a public comment on behalf of the participating discussants.

The last steps - aggregation by an outside body and submission of a unified comment - would not be required if the Department itself were running the website. It could itself create the matrix that would permit commenters to focus their

Government < www.dot.gov/open> but not online: FAA < www.faa.gov/open> where the Federal Aviation Administration is a subunit of the Department of Transportation

Noveck, supra note 41

See supra note 83.

See text accompanying $\mathrm{n} 42$ above.

See online: CERI < http://ceri.law.cornell.edu/>

Online: Regulation Room<http://regulationroom.org/>

Limiting the Use of Wireless Communication Devices, 75 Fed. Reg. 16391, April 1, 2010 (RIN 2126 AB22); online: Regulations.gov <http://www.regula-tions.gov/search/Regs/home.html\#searchResults? $\mathrm{Ne}=11+8+8053+8098+8074+8066+8084+1 \& \mathrm{Ntt}=\mathrm{RIN}+2126 \% 25 \mathrm{e} \% 2580 \% 2593 \mathrm{AB} 22 \&$ $\mathrm{Ntk}=$ All $\& \mathrm{Ntx}=$ mode + matchall $\& \mathrm{~N}=0>$. 
contributions on particular issues, in ways that would be transparent to others interested in the same issues and that would not require responders to search the whole body of comments (as at present) to see if there were any on the particular points that might happen to interest them. Agency staff, after the comment period, would have the significant advantage of a disaggregated collection of comments, arranged point by point, as well as any general inputs that might have been submitted.

Is it realistic to expect discussion of the interactive nature CeRI hopes to promote? Will it be too complicated/costly to present proposed rules, often quite complex and with disparate interrelated sections, in a manner that would facilitate such focused discussion, if it could be expected? And will open discussion actually eventuate? Rulemaking is unlike the construction of a Wikipedia, or even early-stage, free-form consultation on a general question like government openness policy." People have direct stakes in the outcome, possibly momentous ones - and that can both magnify numbers past the relatively few interested volunteers who have thus far appeared in White House on-line consultations, and produce more political behaviour. One can imagine many other questions about the future of the project strongly suggesting, inter alia, that the way forward is by cautious experiment and observation, not across-the-board imposition of a uniform mode of proceeding. Perhaps a threshold determination like that now required for negotiated rulemaking is called for. For the moment, the thing to see is that the presence of the electronic format permits, if it will not necessarily generate, a kind of dialogue about proposed rulemaking that simply could not have been imagined in paper format.

\section{CONCLUSION}

It is a quarter century since I began telling my Administrative Law students that they had better be watching the Internet and how agencies of interest to them were using it, as they entered an Information Age career. The changes since then have been remarkable. Rulemaking, where the pace has perhaps been slowest, is now accelerating into the Internet, driven by a President committed to openness and consultation. This paper seeks little more than to point the reader toward the places where she can find the changes and watch them for herself.

91 Cf. President's Council of Advisors on Science and Technology, online: PCAST

$<$ http://pcast.ideascale.com/> (one of a number of free-form, on-line collaborative discussions the Office of Science and Technology Policy has conducted). 